\title{
Implementasi model integrasi bimbingan dan konseling dalam pendidikan dan penerapannya di sekolah dan madrasah
}

\author{
Rahmad Hidayat ${ }^{*}$ \\ Institut Agama Islam Negeri (IAIN) Curup, Indonesia
}

\section{Article Info \\ Article history: \\ Received Jan $22^{\text {nd }}, 2021$ \\ Revised Feb 20 ${ }^{\text {th }}, 2021$ \\ Accepted Feb 18 $8^{\text {th }}, 2021$}

Keyword:

Integrasi bimbingan dan

konseling;

Pendidikan;

Sekolah dan madrasah

\begin{abstract}
Keberadaan bimbingan dan konseling diberbagai lembaga pendidikan di Rejang Lebong memiliki bentuk program layanan dan karakteristik yang berbeda-beda. Karakteristik di sekolah tersebut, dapat dilihat dari banyaknya program layanan yang diterapkan pada peserta didik, baik itu layanan bimbingan konseling maupun program kedisiplinan, hal ini memerlukan integrasi bimbingan dan konseling dalam pendidikan dan bagaimana konselor mampu menerapkan di sekolah dan madrasah. Program bimbingan dan konseling berupa pelayanan yang dilaksanakan secara holistik di sekolah dan madrasah dengan mengacu kepada pola integrasi bimbingan dan konseling bertujuan untuk keberhasilan pencapaian program-program sekolah dan madrasah, penelitian ini menggunakan pendekatan kulaititif dengan subyek penelitian adalah kepala sekolah dan konselor pada SMAN 5 Rejang Lebong, MAN Rejang Lebong, dan Pesantren Ar-Rahmah Curup, data hasil wawancara, dokumentasi dan observasi dianalisis secara bersamaan melalui reduksi, penyajian, dan verifikasi data. Hasil penelitian menunjukkan bahwa pola integrasi bimbingan dan koseling telah berlangsung dengan sangat baik, dan berjalan dengan optimal, kepala sekolah dan konselor dapat bekerja dengan sangat baik, program-program bimbingan dan konseling telah berjalan dengan optimal.
\end{abstract} BY license (https://creativecommons.org/licenses/by/4.0/)

\section{Corresponding Author:}

Rahmad Hidayat

Institut Agama Islam Negeri (IAIN) Curup

Email: rahmadhidayat@iaincurup.ac.id

\section{Pendahuluan}

Bimbingan adalah suatu proses membantu para individu memahami diri mereka dan dunia mereka (Thompson et al., 2000). Di lingkungan pendidikan formal Pendidikan Dasar dan Menengah melalui Guru Pembimbing dan Pendidikan Tinggi melalui Konselor Perguruan Tinggi, tenaga konseling merupakan salah satu unsur penting yang tidak dapat ditinggalkan dalam dunia pendidikan modern saat ini, karena tidak semua masalah yang berhubungan dengan peserta didik dapat diselesaikan oleh guru mata pelajaran atau dosen pengasuh (Ansary et al., 2015).

Menurut (Belkin, 2005) terdapat lima tugas konselor di lingkungan pendidikan, yaitu (1) providing the students an oppurtunity to talk through his problems, (2) counseling with potential dropouts, (3) counseling with students concerning academic failure, (4) counseling with students in evaluating personal assets and limitations, and (5) counseling with students concerning learning difficulties.

Berdasarkan pendapat Belkin di atas, tugas seorang konselor menjadi sangat penting dan luhur dalam rangka membantu peserta didik mencapai tujuan pendidikan dalam semua dimensi, baik dimensi keindividualan, dimensi kesosialan, dimensi kesusilaan, dan dimensi keberagamaan tanpa dihambat oleh berbagai masalah yang dapat mengganngu proses pendidikannya (Nelissen \& Van den Bulck, 2018).

Tugas konselor menurut (Prayitno \& Amti, 2004) adalah sebagai berikut : (1) memasyarakatkan pelayanan bimbingan dan konseling; (2) merencanakan program bimbingan dan konseling; 
melaksanakan segenap program satuan layanan bimbingan dan konseling; (4) melaksanakan segenap program kegiatan pendukung bimbingan dan konseling; (5) menilai proses dan dan hasil pelaksanan satuan layanan dan kegiatan pendukung bimbingan dan konseling; (6) menganalisis hasil penilaian layanan dan kegiatan pendukung bimbingan dan konseling; (7) melaksanakan kegiatan tindak lanjut berdasarkan hasil penilaian layanan dan kegiatan pendukung bimbingan dan konseling; (8) mengadministrasikan kegiatan satuan layanan dan kegiatan pendukung bimbingan dan konseling yang dilaksanakannnya ; dan (9) mempertanggunjawabkan tugas dan kegiatannnya dalam pelayanan bimbingan dan konseling secara menyeluruh kepada koordinator bimbingan dan konseling.

Perubahan paradigma pendekatan bimbingan dan konseling, yaitu dari pendekatan yang berorientasi tradisional, remedial, klinis, dan terpusat pada konselor, kepada pendekatan yang berorientasi perkembangan dan preventif (Boberiene \& Hornback, 2014). Pendekatan semacam ini dimaknai sebagai pendekatan bimbingan dan konseling perkembangan (Developmental Guidance and Counseling), atau bimbingan dan konseling komprehensif (Comprehensive Guidance and Counseling). Pelayanan bimbingan dan konseling komprehensif didasarkan kepada upaya pencapaian tugas perkembangan, pengembangan potensi dan pengentasan masalah-masalahpeserta didik (dalam istilah bimbingan dan konseling diistilahkan dengan konseli). Tugas-tugas perkembangan dirumuskan sebagai standar kompetensi yang harus dicapai peserta didik/konseli, sehingga pendekatan ini disebut juga bimbingan dan konseling berbasis standar (standard based guidance and counseling). Standar dimaksud adalah standar kompetensi kemandirian.

Menurut (Ristianti, 2017) pendekatan ini menekankan kolaborasi antara guru pembimbing dengan para personil Sekolah/ Madrasah lainnya (pimpinan Sekolah/Madrasah, guru-guru, dan staf administrasi), orang tua konseli, dan pihak-pihak terkait lainnya (seperti instansi pemerintah/swasta dan para ahli, psikolog dan dokter). Pendekatan ini terintegrasi dengan proses pendidikan di Sekolah/Madrasah secara keseluruhan dalam upaya membantu para konseli agar dapat mengembangkan atau mewujudkan potensi dirinya secara penuh, baik menyangkut aspek pribadi, sosial, belajar, maupun karir (Fathurrochman et al., 2019, 2020). Atas dasar itu, maka implementasi bimbingan dan konseling di Sekolah/Madrasah diorientasikan kepada upaya memfasilitasi perkembangan potensi konseli, yang meliputi aspek pribadi, sosial, belajar dan karir; atau terkait dengan pengembangan pribadi konseli sebagai makhluk yang berdimensi biopsiko-sosio-spiritual (biologis, psikis, sosial, dan spiritual).

Berdasarkan paparan di atas, dapat dipahami bahwa peserta didik haruslah mendapat porsi yang lebih concern dalam proses pendidikan, karena indikator keberhasilan pendidikan itu adalah peserta didik, maka pendidik haruslah dapat memahami peserta didik secara holistic dan mendalam. Dengan kata lain, indikator kualitas pendidikan di sekolah terintegral dengan kualitas peserta didik. Kondisi sebagaimana dipaparkan di atas, membuat penulis termotivasi untuk mengkaji lebih mendalam tentang integrasi program bimbingan dan konseling di sekolah (Kipkemboi et al., 2016).

Berbagai hal sebagaimana yang dipaparkan di atas menunjukkan bahwa perlu adanya pembenahan dalam bidang pendidikan, terutama pendidikan formal di sekolah. Salah satu unsur program yang penting dalam peningkatan mutu pendidikian di sekolah adalah keberadaan bimbingan dan konseling yang ironisnya pada beberapa sekolah tidak berjalan secara maksimal sehingga mutu sekolah yang diharapkan tidak tercapai secara maksimal pula (Fitri et al., 2018).

Berdasarkan pengamatan di lapangan, penulis melihat dan menemukan beberapa fakta menarik berkaitan dengan keberadaan bimbingan dan konseling di sekolah, antara lain secara kuantitatif, jumlah petugas bimbingan dan konseling di sekolah (biasanya disebut dengan guru pembimbing) di SMAN lebih banyak dibandingkan dengan jumlah guru pembimbing yang ada di MAN atau bahkan pondok pesantren, namun ternyata jika dikaitkan dengan aspek pengembangan diri dan pembentuksan karakter, pendidikan di pondok pesantren di beberapa tempat ternyata lebih berhasil dari pendidikan di SMAN dan MAN.

Pandangan lebih makro juga akan membenturkan kita antara fungsi keberadaan bimbingan dan konseling di sekolah/ madrasah pada satu pihak dan fakta lapangan di pihak yang lain. Secara konseptual, sejatinya keberadaan bimbingan dan konseling di sekolah dimaksudkan untuk mengisi celah atau kekosongan ataupun keterbatasan pendidikan berkaitan dengan pemahaman, penerimaan, dan pemaknaan peserta didik/ konseli. Bimbingan dan konseling diharapkan menjadi bagian penting untuk ketercapaian tujuan pendidikan nasional sebagaimana tercantum dalam UU nomopr 20 tahun 2003. Namun faktanya walaupun setelah adanya bimbingan dan konseling di sekolah/ madrasah banyak peserta didik (di beberapa tempat) yang masih terjebak dalam kenakalan remaja yang justru bertentangan dengan tujuan bimbingan dan konseling di sekolah. Pemahaman akan fakta ini kemudian berhenti kepada sebuah kesimpulan bahwa telah terjadi kesalahan, baik pada bimbingan dan konseling secara konseptual maupun pelaksanaan atau 
implementasi bimbingan dan konseling secara faktual di lapangan (sekolah/ madrasah). Penulis berasumsi bahwa salah satu upaya untuk lebih memaksimalkan atau memberdaya-gunakan program bimbingan dan konseling di sekolah adalah dengan penguatan program bimbingan dan konseling melalui pola integrasi bimbingan dan konseling dalam sistem pendidikan di sekolah. Melalui pola ini diharapkan pelaksanaan program bimbingan dan konseling di sekolah semakin mendarah daging dengan program kurikulum lainnya. Penelitian ini mengeksplor lebih dalam tentang pola integrasi bimbingan dan konseling dalam pendidikan sekolah/ madrasah dan penerapannya di SMAN 1 Selupu Rejang, MAN Curup, dan Pesantren Ar-Rahmah Curup.

\section{Metode}

Penelitian ini merupakan penelitian kualitatif dengan pendekatan deskriptif dengan tujuan untuk mengkaji secara kualitatif pola integrasi bimbingan dan konseling dalam pendidikan sekolah dan madrasah dan penerapannya di SMAN 1 Selupu Rejang, MAN Curup, dan Pesantren Ar-Rahmah Curup dan implikasinya dalam peningkatan peran bimbingan konseling dengan jenis pendekatan yang digunakan adalah pendekatan kualitatif (Komariah \& Kurniady, 2017). Responden dalam penelitian adalah kepala sekolah dan konselor pada ketiga sekolah tersebut yang menerapkan proses bimbingan konseling, pemilihan subyek penelitian dilakukan berdasarkan kriteria yang telah ditetapkan peneliti yaitu konselor yang bertugas pada sekolah masing-masing (Murfi et al., 2020). Metode pengumpulan data dalam penelitian ini menggunakan metode yang merujuk pada jenis penelitian ini, yaitu wawancara, observasi dan dokumentasi. Data hasil wawancara, dokumentasi dan observasi dianalisis secara bersamaan melalui reduksi, penyajian, dan verifikasi data yang dilaksanakan, Fathurrochman (2019). Dari hasil analisis data yang kemudian dapat ditarik kesimpulan, berdasarkan penjelasan tersebut maka peneliti menarik kesimpulan dan melakukan verifikasi data.

\section{Hasil dan Pembahasan}

Sebelum membahas lebih jauh tentang bimbingan dan konseling di sekolah, akan dikemukakan terlebih dahulu tentang pengertian bimbingan dan konseling. Berdasarkan hasil Kongres Nasional VIII IPBI di Surabaya 14-16 Desember 1995 dalam halaman mukaddimah dikemukkan bahwa: bimbingan dan konseling adalah bantuan yang diberikan tenaga profesional bimbingan dan konseling kepada peserta didik dan anggota masyarakat lainnya agar mereka mampu memperkembangkan potensi yang dimiliki, mengenali dirinya sendiri, serta mengatasi permasalahannya sehingga dapat menentukan sendiri jalan hidupnya secara bertanggung jawab tanpa tergantung kepada orang lain Berdasarkan pengertian di atas, bimbingan dan konseling harus dilakukan oleh tenaga profesional (berlatar belakang pendidikan bimbingan dan konseling) dengan tujuan pengembangan potensi individu demi tercapainya kemandirian (Prayitno \& Amti, 2004).

Senada dengan pengertian di atas (Davis et al., n.d.) merumuskan bimbingan dan konseling merupakan pertolongan yang diberikan oleh seseorang (yang sudah dipersiapkan dalam bidang spesialisasi) kepada orang lain yang memerlukan, dengan, tujuan menolong orang tersebut dalam mencapai kehidupan yang layak dan bahagia dalam masyarakat.

Pendapat sedikit berbeda disampaikan oleh Muhammad Surya yang mendefenisikan bimbingan dan konseling sebagai proses pemberian bantuan yang terus-menerus dan sistematis dari konselor/ pembimbing kepada yang dibimbing agar tercapai kemandirian dalam pemahaman, pengarahan, aktualisasi, dan penyesuaian diri (Fitri et al., 2018). Dalam persepsi Islam, bimbingan juga penting. Hal ini dapat dilihat dari pendapat Masdar Hilmi yang mengatakan bahwa bimbingan sejatinya implementasi dari dakwah yang diwajibkan Islam agar individu dapat melaksanakan keseimbangan hidup di dunia dan akhirat secara tepat (T. Baskin et al., n.d.; Ristianti et al., 2019).

Berdasarkan perspektif psikologis, bimbingan dan konseling diperlukan untuk memelihara kesehatan mental serta terhindar dari gangguan mental. Kesehatan mental ialah terwujudnya kesehatan yang sungguhsungguh antara fungsi fungsi kejiwaan dan tercapainya penyesuian diri antara manusia dengan dirinya dan lingkungannya. Berasarkan keimanan dan ketaqwaan, serta bertujuan untuk mencapai hidup yang bermakna dan bahagia di dunia dan diakhirat (Fitri et al., 2018). Mental yang sehat pada akhirnya akan membawa individu kepada kebahagiaan. Kebahagiaan merupakan hal yang diinginkan oleh semua orang, dan setiap orang memiliki pendapat serta pandangan yang berbeda tentang hakikat kebahagiaan serta cara untuk mendapatkannya. Mental yang sehat juga dimaksudkan sebagai kondisi optimal dari aspek intelektual dan emosional sehingga perilakunya tidak guncang oleh situasi yang berubah di lingkungannya (Gysbers, 
Norman C.; Henderson, 2014). Melalui berbagai kalimat dan pernyataan, dalam al-Qur'an diungkapkan adanya kebahagiaan, kesenangan, kegembiraan, kenikmatan, kesejahteraan, kelezatan, kemuliaan dan sebagainya, yang merupakan tumpuan cita dan harapan manusia dalam kehidupannya (Pribadi, 2014).

\section{Bimbingan dan Konseling di Sekolah dan Madrasah}

Landasan formal di atas mengisyaratkan bahwa pelayanan bimbingan dan konseling perlu dilaksanakan secara menyeluruh di sekolah dan seluruh staf pengajar secara langsung terlibat dalam pelaksanaan pelayanan tersebut. Dalam hal ini pelayanan bimbingan dan konseling tidak lagi dianggap sebagai usaha atau pelayanan sampingan atau sambil lalu ataupun sewaktu-waktu saja, namun menjadi bagian yang terpadu di dalam keseluruhan proses, pendidikan dan pembinaan siswa di sekolah. Bimbingan dan konseling pada dasarnya merupakan bagian integral dari proses pendidikan dan memiliki kontribusi terhadap keberhasilan pendidikan di sekolah (Iswari, 2018). Bimbingan dan konseling sejak mula keberadaannya di Indonesia ternyata lebih mendapat tempat dan berkembang pada segmen pendidikan formal dibanding dengan segmen lainnya seperti pada pendidikan keluarga (informal) maupun pendidikan di masyarakat (non-formal). Bila diperhatikan faktor-faktor yang melatar belakangi perlunya pelayanan bimbingan dan konseling di sekolah atau lembaga pendidikan, maka nampaknya kehadiran bimbingan dan konseling tidak hanya merupakan keharusan, tetapi juga menuntut suatu lembaga dan tenaga profesional dalam pengelolaannya. Karena itu, sejatinya sekolah dan madrasah memiliki tanggung jawab besar untuk membantu siswa agar berhasil dalam belajar (Rusandi et al., 2019).

Proses curah personalis di sekolah dapat dimulai dengan menegaskan pemilahan peran yang saling berkomplemen. Bimbingan konseling dengan para konselornya disandingkan dengan bagian kesiswaan. Wakil kepala sekolah bagian kesiswaan dihadirkan untuk mengambil peran disipliner dan hal-hal yang berkait dengan ketertiban serta penegakan tata tertib. Siswa membolos, berkelahi, pakaian tidak tertib, bukan lagi konselor yang menegur dan memberi sanksi. Reward dan punishment, pujian dan hukuman adalah dua hal yang mesti ada bersama-sama. Pemilahan peran demikian memungkinkan bimbingan dan konseling optimal dalam banyak hal yang bersifat reward atau peneguhan. Jika tidak demikian, bimbingan dan konseling lebih mudah terjebak dalam tindakan hukum-menghukum. Oleh karena itu mendesak untuk diwujudkan, prinsip keseimbangan dalam pendampingan orang-orang muda yang masih dalam tahap pencarian diri. Orang-orang muda di sekolah menengah lazimnya dihadapkan pada celaan, cacian, cercaan, dan segala sumpah-serapah kemarahan jika membuat kekeliruan. Namun, jika melakukan hal-hal yang positif atau kebaikan, kering pujian, sanjungan atau peneguhan. Betapa ketimpangan ini membentuk pribadi-pribadi yang memiliki gambaran diri negatif belaka. Jika seluruh komponen kependidikan di sekolah bertindak sebagai yang menghakimi dan memberikan vonis serta hukuman, maka semakin lengkaplah pembentukan pribadi-pribadi yang tidak seimbang (Fua et al., 2018).

Bimbingan dan konseling dapat diposisikan secara tegas untuk mewujudkan prinsip keseimbangan. Lembaga ini menjadi tempat yang aman bagi setiap siswa untuk datang membuka diri tanpa waswas akan privacy-nya. Di sana menjadi tempat setiap persoalan diadukan, setiap problem dibantu untuk diuraikan, sekaligus setiap kebanggaan diri diteguhkan. Bahkan orangtua siswa dapat mengambil manfaat dari pelayanan bimbingan di sekolah, sejauh mereka dapat ditolong untuk lebih mengerti akan anak mereka (Almafaluti et al., 2018).

Tantangan pertama untuk memulai suatu proses pendampingan pribadi yang ideal justru datang dari faktor-faktor instrinsik sekolah sendiri. Kepala sekolah kurang tahu apa yang harus mereka perbuat dengan konselor atau guru-guru pembimbing. Ada kekhawatiran bahwa konselor akan memakan "gaji buta". Akibatnya, konselor mesti disamping tugas-tugas mengajar keterampilan, sejarah, jaga kantin, mengurus perpustakaan, atau jika tidak demikian hitungan honor atau penggajiannya terus dipersoalkan jumlahnya. Sesama staf pengajar pun mengirikannya dengan tugas-tugas konselor yang dianggapnya penganggu terselubung. Padahal, betapa pendampingan pribadi menuntut proses administratif dalam penanganannya (Kipkemboi et al., 2016).

Bimbingan dan Konseling yang baru dilirik sebelah mata dalam proses pendidikan tampak dari ruangan yang disediakan. Bisa dihitung dengan jari, berapa jumlah sekolah yang mampu menyediakan ruang konseling memadai. Tidak jarang dijumpai, ruang bimbingan dan konseling sekadar bagian dari perpustakaan (yang disekat tirai), atau layaknya ruang sempit di pojok dekat gudang dan toilet. Betapa mendesak untuk dikedepankan peran bimbingan dan konseling dengan mencoba menempatkan kembali pada posisi dan perannya yang hakiki. Menaruh harapan yang lebih besar pada bimbingan dan konseling dalam pendampingan pribadi, sekarang ini begitu mendesak, jika mengingat kurikulum dan segala orientasinya tetap saja menjunjung supremasi otak. Untuk memulai mewujudkan semua itu, butuh 
perubahan paradigma para kepala sekolah dan semua pihak yang terlibat dalam proses kependidikan (Knight, 2015).

(Ansary et al., 2015) mengemukakan bahwa terdapat beberapa alasan mengapa pada lembaga pendidikan formal diperlukan petugas bimbingan dan konseling (dikenal dengan istilah Guru Pembimbing) yang khusus menangani dan melaksanan program layanan bimbingan dan konseling di sekolah, yaitu (1) Ada beberapa masalah dalam pendidikan dan pengajaran, yang tidak mungkin diselesaikan hanya oleh guru sebagai staf pengajar, karena pada umumnya guru lebih banyak menggunakan waktunya untuk melaksanakan tugas dan tanggung jawabnya dalam kegiatan pengajaran. Masalah tersebut misalnya, pengumpulan data tentang peserta didik. penyelesaian masalah pribadi atau sosial dan lain sebagainya. (2) Pekerjaan menyelesaikan masalah pribadi dan sosial kadang-kadang memerlukan keahlian tersendiri. Penanganan masalah ini akan sangat sulit dilaksanakan oleh staf pengajar yang telah dibebani tugas dalam bidang intruksional. (3) Dalam situasi tertentu kadang-kadang terjadi konflik antara peserta didik dengan guru, sehingga dalam situasi tersebut sangat sulit bagi guru untuk menyelesaikannya sendiri. Untuk itu perlu adanya pihak ketiga yang clapat membantu penyelesaian konflik tersebut. (4) Dalam. situasi tertentu juga dirasakan perlunya suatu wadah atau lembaga untuk menampung dan menyelesai masalah-masalah peserta didik yang tidak dapat tertampung dan terselesaikan oteh para pendidik. Misalnya, bila terjadi ada seorang siswa yang menghadapi masalah pribadi yang cukup serius. Para pendidik kadang-kadang merasa bukan wewenangnya untuk membantu peserta didik tersebut. Sehingga bilamana bidang pembinaan pribadi -bimbingan dan konseling tidak ada atau tidak berfungsi peserta didik tersebut akan tetap dalam keadaaan bermasalah, karena tidak adanya wadah dan tenaga yang dapat membantunya dalam. menyelesaikan masaalah yang dihadapinya (Stulmaker \& Ray, 2015). Berdasarkan hasil dan pembahasan di atas, dapat ditemukan kedudukan pelayanan bimbingan dan konseling dalam keseluruhan pendidikan di sekolah, yaitu sebagai salah satu upaya pribadi peserta didik.

\section{Pola Integrasi Bimbingan dan Konseling dalam Sistem Pendidikan di Sekolah}

Bimbingan dan konseling yang berkedudukan sebagai integral dari keseluruhan kegiatan pendidikan di sekolah dalam pelaksanaannya mempunyai beberapa pola atau kemungkinan operasionalnya. Berdasarkan pengamatan dan pendapat tokoh, terdapat beberapa pola integrasi antara bimbingan konseling dengan pendidikan (lingkup sekolah) secara komprehensif dapat kita temukan sebagaimana dalam penjelasan dibawah ini.

Pola bimbingan dan konseling yang identik dengan Pendidikan, Menurut pola ini bimbingan itu identik dengan pendidikan, karena baik prinsip maupun tujuan yang ingin dicapai adalah sama, yakni mengantarkan individu peserta didik untuk pertumbuhkan dan memperkernbangkan dirinya secara optimal.

Perbedaan antara. pendidikan dan bimbingan hanya terletak pada metode dan fokus perhatiannya. Adapun indikator pola bimbingan identik dengan pendidikan ini adalah : (1) Adanya anggapan bahwa membimbing adalah mendidik dan mendidik adalah membimbing. (2) Setiap pendidik disamping berfungsi sebagai pengajar juga berfungsi sebagai pembimbing. (3) Pendidik pada waktu memberikan materi pelajar (mengajar) sekaligus memasukkan unsur-unsur bimbingan. (3) Biasanya pada pola ini orang beranggapan bahwa tidak perlu untuk membentuk lembaga khusus bimbingan penyuluhan. (4) Adapun kebaikan pola bimbingan identik dengan pendidikan ini adalah : (a) bimbingan dan konseling betul-betiul terintegral dengan pendidikan, dan (b) seluruh pendidik berperan serta secara penuh dalam kegiatan bimbingan dan konseling. Namun pola ini bukannya tanpa kelemahan.

Setidaknya terdapat dua kelemahan dalam pola ini, yaitu : (a) metode serta teknik bimbingan dan konseling yang sudah berkembang pesat tidak dapat dimanfaatkan oleh para pendidik, karena mereka kurang banyak dibekali dengan pengetahuan dan keterampilan yang memadai untuk melaksanakan fungsinya sebagai konselor. Dengan demikian, dapat diperkirakan bahwa keberhasilan mereka memberikan bimbingan dan konseling kurang terjamin dan (b) banyak program bimbingan dan konseling yang membutuhkan penanganan yang khusus dan tenaga yang profesional serta pada waktu yang khusus pula.

Pola bimbingan dan konseling berperan hanya sebagai pelengkap pendidikan. Pola ini beranggapan bahwa di dalam sistem pendidikan yang berjalan sekarang, banyak ditemukan celah celah dan kekurangangan. Sistem pendidikan klasikal yang konvensional banyak memperhatikan kelas dan keseluruhan peserta secara umum, tetapi kurang memperhatikan peserta didik individu yang unik. Perbedaan individual kurang mendapat perhatian yang proporsional, sehingga menghambat pertumbuhan dan perkembangan yang sedang dilalui oleh individu peserta didik. Dalarn hal ini bimbingan dan penyuluhan berfungsi sebagai jembatan yang mengantarai atau menutupi celah-celah atau kekurangan yang ditemukan dalarn pengajaran klasikal tersebut (T. W. Baskin \& Slaten, 2014). 
Indikator-indikator dari pola ini adalah : (1) Lembaga bimbingan dan konseling dibentuk khusus yang sifatnya relatif eksklusif, dan ditangani oleh para ahli dari berbagai bidang. (2) Fungsi bimbingan dan konseling terpisah dari kegiatan instruksional. Dalam hal ini bimbingan dan konseling bertugas untuk menangani hal-hal yang tidak tersentuh/terjangkau oleh pengajaran, terutama berhubungan dengan problem, kebutuhan dan perbedaan individual. (3) Program bimbingan dan konseling pada pola kedua ini cenderung mengarah pada pelayanan yang bersifat klinikal dengan fungsi utama remediatif - rehabilitatif adjustif. (4)Orientasinya lebih mengarah dan ditekankan pada masalah peserta didik yang mengalami krisis.

Kelebihan dan kebaikan dari pola kedua ini adalah setiap peserta didik yang mengalami problem dan masalah tertentu mendapat penanganan dan bantuan yang serius dan mernuaskan dari para ahlinya, sedangkan kelemahan pola bimbingan sebagai petengkap pendidikan ini adalah : (a) tenaga-tenaga para ahli seperti psikolog, psikiater, dokter dan lain sebagainya sering sukar diperoleh dan biasanya lebih mahal, (b) cara kerja lembaga pada pola kedua ini cenderung ekslusif, ingin bebas dan memisahkan diri dari kegiatan-kegiatan lainnya seperti kegiatan pengajaran dan administrasi, (c) pola ini hanya mengutamakan mambantu peserta didik yang mempunyai problem saja, sedangkan peserta didik yang lain yang jumlahnya lebih banyak terabaikan, dan (d) pendidik (Guru/dosen) cenderung bersikap tidak acuh terhadap masalah siswa walau bagaimana pun kedinya, karena sudah ada lembaga khusus yang akan menanganinya.

Pola bimbingan dan konseling bagian dari kurikuler. Adapun indikator dari pola ini adalah : (1) Disediakannya jam-jam pelajaran khusus memberikan pelayanan bimbingan secara kelompok. (2) Dalam hal ini pembimbing berdiri di muka kelas untuk membahas hal-hal yang dirasa perlu dalarn menunjang kelancaran dan kesukaran studi peserta didik. (3) Materi yang diberikan di muka kelas antara lain hal-hal yang berhubungan dengan masalah cara belajar.

Kelebihan dan kebaikan dari pola ini adalah (a) peserta didik memperoleh dasar-dasar orientasi psikologis dari kehidupan sekarang dan di masa yang akan datang, (b) pelayanan bimbingan dan konseling lebih berkesinambungan, bukan merupakan usaha penyernbuhan yang insidental saja, (c) konselor (dalam hal ini guru pembimbing) memiliki sarana untuk berhubungan secara langsung dengan peserta didik di kelas maupun di luar kelas, dan (d) kedudukan guru pembimbing sama dan sejajar dengan staf pengajar lainnya, sehingga kesan bahwa guru pembimbing sama dengan polisi/penjaga. ketertiban. sekolah atau tenaga administrasi dapat dihilangkan.

Kelemahan pola bimbingan bagian dari kurikuler ini adalah : (a) jam pelajaran atau kredit perkuliahan menjadi terkurangi, (b) guru pembimbing dituntut untuk memiliki dua kualifikasi yang cukup berat yakni menjadi guru pembimbing yang baik dan sekaligus menjadi pendidik yang cakap, dan (c) diperlukan jumlah tenaga guru pembimbing yang cukup banyak. kalau tidak demikian guru pembimbing akan menjadi terlalu sibuk karena harus mengisi jam pelajaran, guru pembimbing akan menjadi terlalu sibuk karena harus mengisi jam pelajaran/perkuliahan pada sejumlah kelas, di samping tugas pokok sebagai guru pembimbing.

Pola bimbingan dan konseling bagian dari layanan urusan kesiswaan. Adapun indikator dari pola ini adalah sebagai berikut (1) Pelayanan bimbingan dan konseling merupakan bagian dari serangkaian kegiatan pembinaan pribadi peserta didik, yang melembaga untuk mendukung kesuksesan dan kelancaran studi para peserta didik. (2) Unit-unit kegiatan pelayanan pembinaan urusan kesiswaan itu meliputi, antara lain layanan kesehatan fisik, layanan konseling, layanan transportasi, layanan pemondokan atau asrama, layanan penyaluran bakat dan minat, layanan kegiatan organisasi mahasiswa, layanan bantuan keuangan melalui bea siswa, ikatan dinas, kredit mahasiswa, layanan pelatihan dan penempatan jabatan, layanan informasi kehidupan kampus, layanan bagi mahasiswa asing dan lain sebagainya. (3) Pelayanan bimbingan dan konseling sebagai bagian dari kegiatan kesiswaan, yang menitik beratkan fungsinya dalam memberikan konseling kepada para peserta didik dengan strategi pendekatan yang juga cenderung ke arah remediatif-rehabilitatif .

Kelebihan dan kebaikan dari pola ini adalah bahwa, aspek-aspek kebutuhan para, peserta didik yang berhubungan dengan kesejahteraan pendidikan dan pribadi mendapat perhatian dan pelayanan yang baik oleh masing-masing unit yang tersedia. Tiap unit pelayanan memperhatikan setiap kebutuhan peserta didik yang tertuang program kerja yang relevan dengan bidangnya masing-masing, sedangkan kelemahannyai adalah: (a) sering terjadi kurangnya koordinasi atau kerja sama yang harmonis antara masing-masing unit pelayanan dan (b) pada umumnya kelemahan-kelemahan yang terdapat pada pola kedua, yaitu bimbingan dan konseling hanya berperan sebagai pelengkap (tenaga-tenaga para ahli seperti psikolog, psikiater, dokter dan lain sebagainya sering sukar diperoleh dan biasanya lebih mahal, cara kerja lembaga pada pola kedua ini cenderung ekslusif, ingin bebas dan memisahkan diri dari kegiatan-kegiatan lainnya seperti kegiatan pengajaran dan administrasi, pola ini hanya mengutamakan mambantu peserta didik yang mempunyai 
problem saja, sedangkan peserta didik yang lain yang jumlahnya lebih banyak terabaikan, dan pendidik (guru/dosen) cenderung bersikap tidak acuh terhadap masalah siswa walau bagaimana pun kecilnya, karena sudah ada lembaga khusus yang akan menanganinya, menjadi kelemahan pula pada pola keempat.

Pola bimbingan dan konseling sebagai sub sistem pendidikan. Sistem bimbingan dan konseling merupakan sub sistem pendidikan, yang saling berhubungan dan bekerja sama pula untuk mencapai tujuan pendidikan yang lebih luas. Indikator dari pola ini adalah sebagai berikut (1) Fungsi pokok bimbingan dan konseling adalah mengusahakan terselanggaranya suasana suasana pembelajaran yang sehat dan sejahtera . Titik berat orientasinya ditujukan kepada para peserta didik yang sedang mengalami masalah maupun tidak (Guidancefor all). (2) Perlu dibentuk lembaga bimbingan dan konseling yang dikelola oleh tenaga yang professional disamping dibantu oleh tenaga pengajar. (3) Kerja bimbingan dan konseling tidak terbatas hanya di ruang bimbingan clan koseling, tetapi program bimbingan dapat dilaksanakan di mana saja baik di kelas dan lain sebagainya. (4) Pendekatan bimbingan. bersifat operasional, mempunyai jangkauan yang cukup luas dan bersifat, pemahaman, pencegahan, pengentasan dan pengembangan.

Kelebihan dan kebaikan dari pola bimbingan sebagai sub sistem pendidikan adalah sebagai berikut: (a) bimbingan tidak terpisah dari proses dan program pendiclikan, karena ia merupakan sub sisrem pendidikan yang eksistensinya tidak dapat diragukan lagi, (b) seluruh personil pendidikan, baik sebagai guru maupun tenaga administrasi berperan aktif dalarn kegiatan pelayanan bimbingan dan konseling, dan (c) seluruh siswa mendapat kesempatan yang sama untuk memperoleh pelayanan bimbingan dan konseling baik secara langsung maupun tidak langsung. Sedangkan kelemahan kelemahan dari pola kelima ini adalah: (a) Konsep pola kelima ini sangat ideal akan tetapi petunjuk operasional sering kurang jelas sehingga. pelaksanaannya sering menemukan kesulitan, (b) bila job discription kurang baik, maka akan sering terjadi kesimpang siuran (overlapping) antara fungsi kepala sekolah dengan guru pembimbing.

\section{Integrasi Program Bimbingan dan Konseling di Sekolah dan Madrasah}

Bimbingan dan konseling sebelumnya yang hanya menekankan pada konseling dan pendampingan murid guna menjembatani komunikasi antar lini sekolah dan orang tua. Kini dalam kurikulum terbaru bimbingan dan konseling memiliki peran sentral bukan saja pada garapan konseling individu, belajar, sosial, dan karir bahkan lebih dengan membawahi unit pengembangan diri yang lebih dikenal dengan ekstrakurikuler (Risdianto et al., 2021).

Pengembangan diri menjadi salah satu lahan garap konseling, tetapi sejauh mana peran guru bimbingan dan konseling (guru pembimbing) membawahi suatu unit kerja notabene dari dulu hanya menjadi pelampiasan murid berkreatifitas secara asal atau sungguh-sungguh. Akuisisi bimbingan dan konseling dengan disiplin ilmunya ke dalam unit ektrakurikuler tak hanya memberi pertimbangan arah pengembangan diri tetapi juga menyelaraskan kreatifitas anak didik dengan sekolah. Tantangan yang muncul adalah bagaimana dengan independesi kreatifitas yang lahir dari intuisi unit ektrakurikuler yang mapan. Sikap ini nampak dari hasil perubahan paradigma berfikir masing-masing unit. Secara sederhana dapat dianalogikan bahwa berfikir adalah bingkai sebuah kacamata sedang sikap adalah lensanya, maka sikap terkurung dalam paradigma. Saatnya pendidik dan semua unit-unit meletakkan anak didik bukan sebagai obyek ajar ajar melainkan subyek yang ikut terlibat dalam bentuk learning how to think (belajar tentang) dan learning how to do (belajar bagaimana) agar lebih menjadi dewasa yaitu mampu menyeimbangkan keberanian (courage) dengan pertimbangan (consideration) (Fitri et al., 2018).

Berdasarkan hasil wawancara pada 15 Januari 2021 diperoleh penjelasan dari kepala sekolah SMAN 5 Rejang Lebong bahwa integrasi program bimbingan dan konseling di sekolah, berjalan dengan sangat baik, demikian pula kepala MAN Rejang Lebong, dan Kepala Pesantren Ar-Rahmah Curup memberikan jawaban yang menguatkan bahwa peran konselor sangat signifikan dalam menjalankan program bimbingan dan konseling di sekolah dan madrasah, skrip wawancara sebagaimana berikut.

"Konselor telah menjalankan tugas dengan sangat baik dan memahami bagaimana melaksankan tugas pembimbingan terhadap siswa pada SMAN 5, diantaranya Fitriyani, S.Pd, yang saya ketahui mampu menjalankan tugas, pokol dan fungsi sebagai konselor, integrasi bimbingan dan konseling ini menjadi sangat baik pelaksanaanya dibawah kendali konelor yang memiliki kompetensi sangat baik" (Wawancara dengan Kepala Sekolah SMAN 5 Rejang Lebong, 18 januari 2021).

"Guru bimbingan dan konseling di MAN Rejang Lebong sudah melaksanakan tugas dengan sangat baik, terkait dengan integrasi saya rasa sudah berjalan sesuai dengan peraturan yang berlaku, saya sangat berharap guru bimbingan dan konseling di MAN Rejang Lebong ini tidak hanya dua orang, tetapi dapat memenuhi jumlah siswa kami yang sangat banyak, saya berharap dengan kinerja yang lebih baik, dengan penambahan jumlah 
guru BK saya rasa kinerja dapat terpenuhi". (Wawancara dengan Kepala Sekolah MAN Rejang Lebong, 17 januari 2021).

"Sebagai kepala pesantren Ar-Rahmah, saya faham betul bagaimana karakteristik santri disini, saya merasa sangat terbantu dengan adanya konselor, saya kira integrasi ini sangat penting, dimana madrasah dan keluarga santri saling menjalin komunikasi dan yang mampu membantu menjembatani adalah guru BK, guru BK sudah melaksankan tugas dengan sangat baik" (Wawancara dengan Kepala pesantren Ar-Rahmah Rejang Lebong, 16 januari 2021).

Berdasarkan data yang diperoleh dari Kepala SMAN 5, Kepala MAN, dan Kepala Pesantren ArRahmah Rejang Lebong mengarahkan integrasi kegiatan bimbingan dan konseling pada sekolah dan madrasah melalui program dan layanan bimbingan konseling dapat berjalan dengan sangat efektif.

\section{Simpulan}

Tujuan pendidikan dapat dicapai secara maksimal di sekolah dan madrasah terutama dalam pengembangan segenap potensi peserta didik tidak hanya kognitif saja merupakan salah satu penyebab urgnesi bimbingan dan konseling di sekolah dan madrasah. Fokus masalah dalam artikel ilmiah ini berkaitan dengan pola integrasi bimbingan dan konseling di sekolah. Penulis memberikan kesimpulan dalam penelitian ini bahwa pada SMAN 5 Rejang Lebong, MAN Rejang Lebong, dan Pesantren Ar-Rahmah Curup telah tercapai program bimbingan dan konseling, berupa pelayanan bimbingan dan konseling yang dilaksanakan secara menyeluruh di sekolah dan madrasah tersebut oleh konselor secara khusus dan secara umum oleh seluruh staf pengajar baik secara langsung terlibat dalam pelaksanaan pelayanan tersebut, maupun secara tidak langsung dalam kegiatan kokurikuler. Dalam hal ini pelayanan bimbingan dan konseling tidak lagi dianggap sebagai usaha atau pelayanan sampingan atau sambil lalu ataupun sewaktu-waktu saja, namun menjadi bagian yang terpadu di dalam keseluruhan proses, pendidikan dan pembinaan siswa di sekolah. Berdasarkan pengamatan dan pendapat kepala sekolah dan konselor, terdapat beberapa pola integrasi antara bimbingan konseling dengan pendidikan (lingkup sekolah) secara komprehensif, yaitu (1) pola bimbingan dan konseling yang identik dengan pendidikan, (p) Pola bimbingan dan konseling berperan hanya sebagai pelengkap pendidikan, (3) pola bimbingan dan konseling bagian dari kurikuler, dan (4) pola bimbingan dan konseling bagian dari layanan urusan kesiswaan, dimana seluruh pola tersebut dapat dilakukan secara integratif pada lokasi penelitian ini.

\section{References}

Almafaluti, A. A. A., Nugroho, S. M. S., \& Purnomo, M. H. (2018). Classifying beneficiaries of islamic boarding school rehabilitation aid based on neural network approaches: A case of the religious affair ministry of East Java. 2018 International Conference on Information and Communications Technology, ICOIACT 2018, 2018-Janua, 454-459. https://doi.org/10.1109/ICOIACT.2018.8350784

Ansary, N. S., Elias, M. J., Greene, M. B., \& Green, S. (2015). Guidance for Schools Selecting Antibullying Approaches: Translating Evidence-Based Strategies to Contemporary Implementation Realities. In Educational Researcher (Vol. 44, Issue 1, pp. 27-36). SAGE Publications Inc. https://doi.org/10.3102/0013189X14567534

Baskin, T., Psychologist, C. S.-T. C., \& 2014, undefined. (n.d.). Contextual school counseling approach: Linking contextual psychotherapy with the school environment. Journals. Sagepub.Com. Retrieved July 21, 2020, from https://journals.sagepub.com/doi/abs/10.1177/0011000012473664

Baskin, T. W., \& Slaten, C. D. (2014). Contextual School Counseling Approach: Linking Contextual Psychotherapy With the School Environment. The Counseling Psychologist, 42(1), 73-96. https://doi.org/10.1177/0011000012473664

Belkin, G. (2005). Introduction to counseling (17th ed.). WCB/McGraw-Hill.

Boberiene, L. V., \& Hornback, B. J. (2014). How can policy strengthen community support for children in military families? The American Journal of Orthopsychiatry, 84(5). https://doi.org/10.1037/h0099862

Davis, E., Health, J. P.-J. of C. in M., \& 2014, undefined. (n.d.). Child-centered play therapy: A creative approach to culturally competent counseling. Taylor \& Francis. Retrieved July 21, 2020, from https://www.tandfonline.com/doi/abs/10.1080/15401383.2014.892863

Fathurrochman, I., Kusen, Rahman, Y., Sukmana, A. T., \& Indarto, H. (2020). The Public Relations Strategies at Higher Education in Indonesia. 7(08), 2745-2752. 
Fathurrochman, I., Ristianti, D. H., \& Arif, M. A. S. bin M. (2019). Revitalization of Islamic Boarding School Management to Foster the Spirit of Islamic Moderation in Indonesia. Jurnal Pendidikan Islam, 8(2), 239-258. https://doi.org/10.14421/jpi.2019.82.

Fitri, E., Erwinda, L., \& Ifdil, I. (2018). Konsep Adiksi Game Online dan Dampaknya terhadap Masalah Mental Emosional Remaja serta Peran Bimbingan dan Konseling. Jurnal Konseling Dan Pendidikan, 6(2), 211-219. https://doi.org/10.29210/127200

Fua, J. La, Nurlila, R. U., Gunawan, F., \& Wekke, I. S. (2018). Islamic Education on Formation of Environmental Awareness in Pondok Pesantren Indonesia. IOP Conference Series: Earth and Environmental Science, 156(1). https://doi.org/10.1088/1755-1315/156/1/012035

Gysbers, Norman C.; Henderson, P. (2014). Developing and managing your school guidance and counseling program.

https://www.google.com/books?hl=id\&lr=\&id=9aCLBgAAQBAJ\&oi=fnd\&pg=PR5\&dq=Guidance +Counseling+children+journal\&ots=orkylm6Ncn\&sig=aHy_vYnci9eKF-YAmY9NoZF3wa8

Iswari, M. (2018). Character Education in Developing the Careers of Children Special Needs in Vocational Providers School Inclusive. Jurnal Konseling Dan Pendidikan, 6(2), $220-227$. https://doi.org/10.29210/121600

Kipkemboi, V., Ngumi, O., \& Chege, K. (2016). Journal of Education and Practice www.iiste.org ISSN. In ERIC (Vol. 7, Issue 13). Online. www.iiste.org

Knight, J. L. (2015). Preparing Elementary School Counselors to Promote Career Development: Recommendations for School Counselor Education Programs. Journal of Career Development, 42(2), 75 85. https://doi.org/10.1177/0894845314533745

Komariah, A., \& Kurniady, D. A. (2017). Authentic Leadership: Strategy of the Implementation of Madrasah Management of Change. Jurnal Pendidikan Islam, 6(2), 293. https://doi.org/10.14421/jpi.2017.62.293-310

Murfi, A., Fathurrochman, I., Atika, \& Jannana, N. S. (2020). Kepemimpinan Sekolah dalam Situasi Krisis Covid-19 di Indonesia. MANAGERIA: Jurnal Manajemen Pendidikan Islam, 5(1), 119-136.

Nelissen, S., \& Van den Bulck, J. (2018). When digital natives instruct digital immigrants: active guidance of parental media use by children and conflict in the family. Information Communication and Society, 21(3), 375-387. https://doi.org/10.1080/1369118X.2017.1281993

Prayitno, \& Amti, E. (2004). Dasar-dasar bimbingan dan konseling (1st ed.). Rineka Cipta.

Pribadi, Y. (2014). Religious networks in Madura pesantren, Nahdlatul Ulama and Kiai as the core of santri culture. Al-Jami'ah, 51(1), 1-32. https://doi.org/10.14421/ajis.2013.511.1-32

Risdianto, E., Wachidi, W., Riyanto, R., Alexon, A., Fathurrochman, I., \& Kusen, K. (2021). Blended Learning Model Based on Massive Open Online Courses ( MOOCs ) Assisted by Augmented Reality ( BMA ) Model as the Electronic Learning Media in the Pandemic Covid-19. Al-Ishlah: Jurnal Pendidikan, 13(1), 228-241. https://doi.org/10.35445/alishlah.v13i1.470

Ristianti, D. H. (2017). Analisis Hubungan Interpersonal Mahasiswa terhadap Dosen dalam Proses Bimbingan Skripsi. ISLAMIC COUNSELING: Jurnal Bimbingan Konseling Islam, 1(1), 25. https://doi.org/10.29240/jbk.v1i1.229

Ristianti, D. H., Danim, S., Winarto, H., \& Dharmayana, I. W. (2019). The Development Of Group Counselling Assessment Instruments. International Journal of Scientific \& Technology Research, 8(10), 267272. http://www.ijstr.org/paper-references.php?ref=IJSTR-1019-23814

Rusandi, M. A., Sugiharto, D. Y. P., \& Sunawan, S. (2019). Effectiveness of solution-focused group counseling to improve planned happenstance skills of student. Jurnal Konseling Dan Pendidikan, 7(1), 30. https://doi.org/10.29210/127600

Stulmaker, H. L., \& Ray, D. C. (2015). Child-centered play therapy with young children who are anxious: A controlled trial. Children and Youth Services Review, 57, 127-133. https://doi.org/10.1016/j.childyouth.2015.08.005

Thompson, C., Rudolph, L., Henderson, D., \& Dansby, V. (2000). Counseling children. Cole Publishing Company. core/content/view/S1037291100004647 